\title{
Choosing Aquatic Plant Species for High Wastewater Treatment Efficiency through Small Wetland
}

\author{
Onanong Phewnil ${ }^{1}$, Kasem Chunkao ${ }^{2}$, Thanit Pattamapitoon ${ }^{1,2}$, Alongkorn Intaraksa ${ }^{1}$, Orathai Chueawong ${ }^{2}$, \\ Chulabuut Chantrasoon ${ }^{2} \&$ Thassanee Boonprakong ${ }^{1}$ \\ ${ }^{1}$ Department of Environmental Science, Faculty of Environment, Kasetsart University, Bangkok, Thailand \\ ${ }^{2}$ The King's Royally Initiated Laem Phak Bia Environmental Research and Development (Royal LERD) Project, \\ Laem Phak Bia Sub-District, Ban Laem District, Phetchaburi Province, Thailand \\ Correspondence: Onanong Phewnil, Department of Environmental Science, Faculty of Environment, Kasetsart \\ University, Bangkok 10900, Thailand. Tel: 66-2579-2116. E-mail: onanong8649@gmail.com
}

Received: May 21, $2014 \quad$ Accepted: May 29, $2014 \quad$ Online Published: June 25, 2014

doi:10.5539/mas.v8n4p187 URL: http://dx.doi.org/10.5539/mas.v8n4p187

\begin{abstract}
The research was aimed to choose the most appropriate aquatic plant in high capacity as grown in small wetland for community wastewater treatment, they were Typha angustifolia Linn., Cyperus corymbosus Rottb., and Canna indica Linn. The small wetland, sometimes called vertical flow constructed wetland (VFCW), has been designated on $100-\mathrm{m}$ long, $5-\mathrm{m}$ wide and $0.75-\mathrm{m}$ deep in size in which four-hole pipes were laid down at the bottom for releasing some treated wastewater as effluent through the outlet to the storage reservoir. There must be paved the gravel on the bottom up to the level of 5-cm height and overtopping with sand about $15 \mathrm{~cm}$ that be followed by 30-cm mixed soil (soil: sand equivalent to 3:1). All selected aquatic plant species were planted in small wetland before flowing community wastewater until soil at saturated level for first week and about $30 \mathrm{~cm}$ during second week up to the maximum age of plants. The choosing aquatic plant species were only depended on the high efficiency of wastewater treatment. The most probable aquatic plant was selected on Typha as the first priority for high wastewater treatment efficiency, Canna the second, and more or less efficiency for the others. Fortunately, Typha has been grown well in everywhere, particularly flat wetland in central, west, east and down north of Thailand.
\end{abstract}

Keywords: aquatic plant, wastewater, small wetland

\section{Introduction}

Thailand had been facing the stream pollution since 1970. H.M. the King Bhumibol has realized the worsen water pollution of the country and studied the possibility on how to recover with nature-by-nature process for longer period of time before starting-up. The King's Royally Initiated Laem Phak Research and Development Project (The Royal LERD Project) has been established in the year of 1990 at Laem Phak Bia Sub-District, Ban Laem District, Phetchaburi Province, the central of Thailand. The nature-by-nature process which is extremely necessary for bacterial organic digestion processes in the tropical latitudes like Thailand as pertained to solar radiation, promising plant species, ecological niche of microorganism for organic digestion processes and plenty of organic matters as pointed out by Metcalf and Eddy (1979); Ye et al. (2001); Yang et al. (2008); Keddy (2010); Penha-Lopes et al. (2012). Actually, wetland is occurred between the terrestrial and aquatic systems in order to absorb the toxic contaminants by humus, organic matters and soils before draining away to stream or river.

Constructed wetland are becoming popular worldwide for removing contaminants from wastewater that are low-cost, easy to operate, and require less maintenance than other wastewater treatment technologies. Constructed wetland have appropriate to treat contaminants from wastewater in developing countries. Aquatic plants are main component of a constructed wetland system. They play important roles in degrading and removing nutrients and other pollutants (Cui et al., 2010). Aquatic plant has eventually to remove contaminants from wastewater and soils as growing units through root system under the osmotic pressure during the photosynthesis processing, then the elements are translocated to accumulate in all parts of vegetative organ, but it depends on the degree of toxic chemical contaminants and aquatic plant species (Tateuyama et al., 1967; Reddy et al., 1990; Rai et al., 1994; De Souza et al., 1999; Marin and Ayele, 2003; Pulford and Watson, 2003; Xia and Ma, 2006; Gupta and Sinha, 2007; Wahla et al., 2008; Thaipichitburapa et al., 2010; Zaier et al., 2010; Chunkao et al., 2012). Many studies have 
demonstrated that variation in nutrient removal efficiencies are attributed to different wetland plants. The principle in selection a suitable plant species for use in constructed wetland system depends on the type of wetland design. However, the choice of plants is an important issue in constructed wetland for wastewater treatment system. The most of constructed wetland system widely used common reed (Phragmite australis), cattails (Typha spp.), bulrushes (Scipus spp.) and reed canarygrass (Phalaris arundinacea) for domestic and industrial wastewater treatment system (Calheiros et al., 2007). Ornamental plants like Canna and Heliconia are used in the small wetlands to increase their aesthetic in tropical area like as Thailand. Both species has been grown well in the wetland system as well as Canna has high growth rate compared to Heliconia (Konnerup et al., 2009). In the other hands, Typha spp. and Cyperus spp. are common used in constructed wetland system in Thailand due to they are generally occurred in every parts of Thailand. Typha is a wetland plant with a very high water demand and limited capacity to close stomata and hence reduce water loss by transpiration. Meanwhile, Cyperus is formed not only in wetlands, but also on drier sites which indicates that this species has higher capacity to tolerate water stress compared to Typha (Kantawanichkul et al., 2009). The present study aimed to (1) investigate the tolerance of plants in small constructed wetland system for domestic wastewater treatment, (2) determine the effect to water quality of domestic wastewater treatment among plant species, and (3) determine the effect of number of rhizobacterium to treatment efficiency among plant species.

\section{Method}

\subsection{Construction of Experimental Units}

The study site is located at Laem Phak Bia sub-district, Ban Laem district, Phetchaburi Province, Thailand. The constructed wetlands have to make to layout on the soil surface, then the volumes of soils from $100 \times 5 \times 1$-cu.m.plot sizes will be excavated with care for bed slope of 1:1,000 together with 45-degree of inclining 4 sides to protect landslide. Consequently, the plot-bed constructed wetlands must be compacted until very less seepage before laying four hole-making PVC pipes for releasing treated wastewater through the pipe-outlet at the bottom of plot bed to public water sources. The second step is focused on to pave the plot bed by gravel with size of 1.0 to $3.0 \mathrm{~cm}$. in diameter about $1.0 \mathrm{~cm}$. height above the hole-making PVC pipes, then topping up by medium to cause sand at about 3 to $5 \mathrm{~cm}$. height above gravel surface, and finally topping up over sand surface by mixed soils (paddy soil: sand $=3: 1$, by weight) until at the level 0.5 of plot depth (1-m depth) (see in Figure 1)
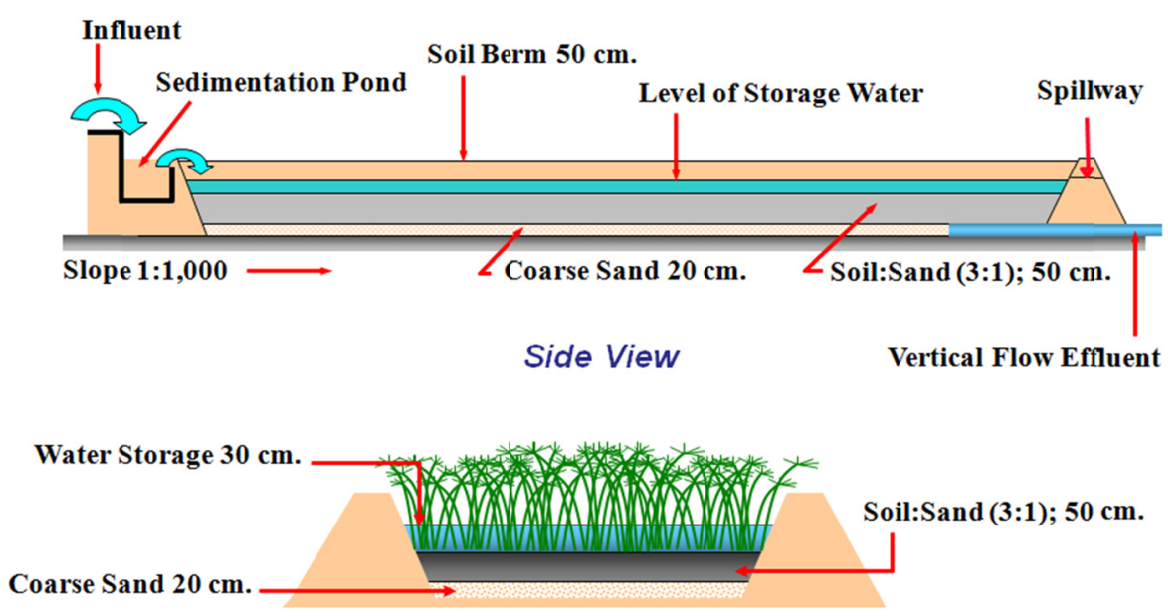

Front View

Figure 1. Plan view of constructed wetland experimental units in The Royal LERD Project

\subsection{Growing Aquatic Plants}

After finished the preparation of constructed wetlands, drained the natural water quality until soils being saturated would be necessary for soils, sand and gravel to adjust themselves for a few days. After that the selected aquatic plant species, Typha angustifolia Linn., Cyperus corymbosus Rottb., and Canna indica Linn., had to grow with $35-\mathrm{cm}$. spacing for 3 replications of each species. After 2 weeks, drained community wastewater into the plots and storage wastewater at the level $30 \mathrm{~cm}$. Measured height of each species every 7 days until flowering stage of plants. 
However, those aquatic plants will be clear cut off after its growth rate equivalent to zero because of very less efficiency of wastewater treatment.

\subsection{Water Quality Analysis}

The basic concept of analyzing water quality has to take from raw wastewater inputs and outputs. In general, the wastewater quality indicators are comprised of the followings: $\mathrm{pH}$, total suspended solid (TSS), biochemical oxygen demand (BOD), total nitrogen (TN) and total phosphorus (TP). The analyzed methods of all indicators as mention above have been formulated by Metcalf and Eddy (1979); Hammer (1989); Grofse and Bauch (1991); APHA (1992); Marin and Ayele (2003); Maine et al. (2006); Hasan et al. (2007); Khan et al. (2009); Keddy (2010); Penha-Lopes et al. (2012).

\subsection{Rhizobacterium Analysis}

The aquatic plant root of each species was collected in the first day of the experiments and every 15 days until the flowering stage of plants. The samples were analyzed for the number of rhizobacterium, isolate of bacteria by dilution techniques with nutrient agar (Delost, 1997; Maier et al., 2000)

\section{Results and Discussion}

\subsection{Growth and Biomass of Aquatic Plants}

Accordance with constructed wetland was proposed to conduct the community wastewater treatment under the stagnated wastewater for 5 days then releasing for 2 days before vertical flow through soil-sand-gravel layer. The experimental findings had pointed out that Typha angustifolia Linn, Cyperus corymbosus Rottb., and Canna indica Linn.) grew well in Phetchaburi municipal wastewater, and also the maximum effective treatment under the constructed wetland concept as shown in Figure 2. Actually, the appropriate cutting period found 90 days, 60 days, 105 days for Typha angustifolia Linn, Cyperus corymbosus Rottb., and Canna indica Linn., respectively.

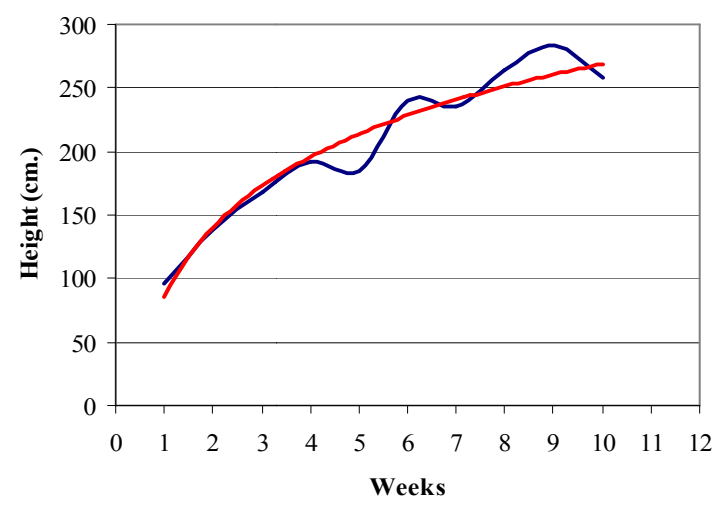

(a) Typha angustifolia Linn.

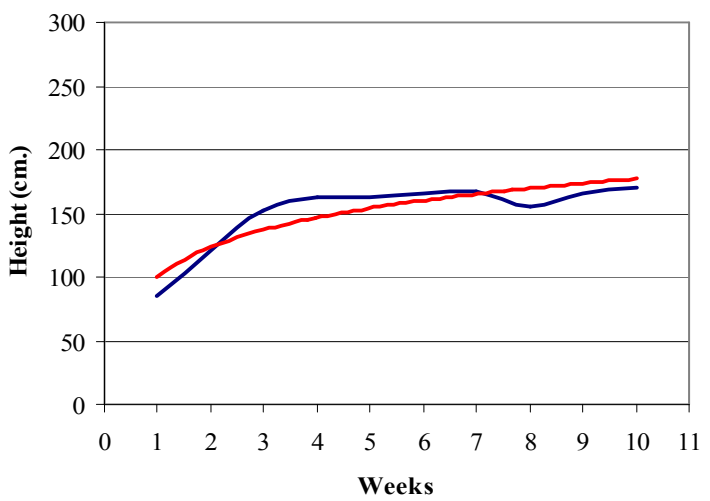

(b) Cyperus corymbosus Rottb.

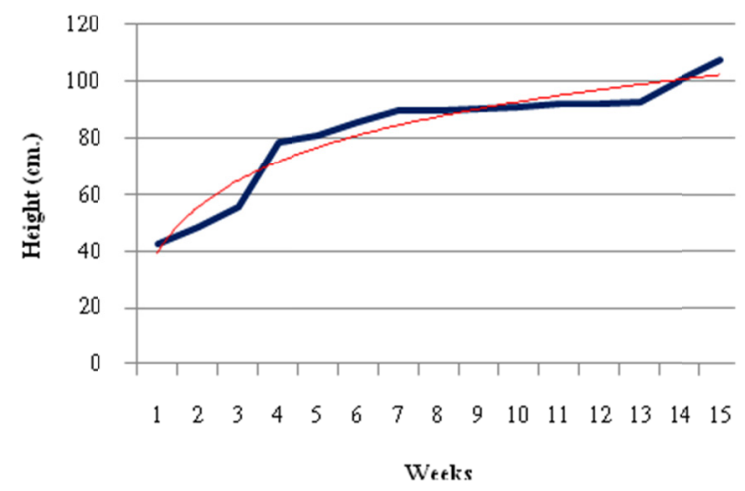

(c) Canna indica Linn.

Figure 2. Determination of cutting period of selected aquatic plants (a) Typha angustifolia Linn., (b) Cyperus corymbosus Rottb. and (c) Canna indica Linn. as used for Phetchaburi municipal wastewater treatment along with 5-day stagnated and 2-day releasing wastewater on the constructed wetland 
Biomass of three aquatic plants were shown in Table 1 which indicated growth production of each plant. The total biomass (stems and rhizomes) after harvesting period, showed that wet weight and dry weight of Canna indica Linn. was greater than Typha angustifolia Linn. and Cyperus corymbosus Rottb, respectively. Wenyin et al. (2007) and Leto et al. (2013) reported that the root growth of Canna with fibril roots was faster than Typha and Cyperus with rhizomatic roots due to fibril roots had higher root number than rhizomatic roots but rhizomatic roots showed a longer root lifespan than those with fibril roots. However, root biomass between the plants with rhizomatic roots and those with fibril roots were not significant. The ratio of shoot biomass to root biomass of Canna and Typha were about 2.94 and 3.10, respectively, which revealed that Canna had belowground yield greater than aboveground but Typha had aboveground yield greater than belowground. In addition, Typha colonized a larger surface area and produced significantly higher yields of aboveground and belowground biomass than Cyperus. Some previous studies reported that Typha in constructed wetlands for peatland restoration showed high biomass production because of the peatland as a sink in the nutrient cycle may be reactivated (Wild et al., 2001) and Canna can grew every well in constructed wetland condition (Konnerup et al., 2009). In the other hands, Typha biomass was probably less than Cyperus in stress condition as lack of water due to Typha needed very high water demand and also limited capacity to close stomata and reduce water loss by transpiration, but Cyperus also survived in drier sites that showed a higher capacity to tolerance water stress (Kantawanichkul et al., 2009).

Table 1. Biomass of Typha angustifolia Linn., Cyperus corymbosus Rottb., and Canna indica Linn. in small constructed wetland system.

\begin{tabular}{lcc}
\hline \multicolumn{1}{c}{ Plants } & Wet weight $\left(\mathrm{g} / \mathrm{m}^{2}\right)$ & Dry weight $\left(\mathrm{g} / \mathrm{m}^{2}\right)$ \\
\hline Typha angustifolia Linn. & $1,380.73^{\mathrm{b}}$ & $283.4^{\mathrm{b}}$ \\
Cyperus corymbosus Rottb. & $503.12^{\mathrm{a}}$ & $170.20^{\mathrm{a}}$ \\
Canna indica Linn. & $2,827.10^{\mathrm{c}}$ & $465.50^{\mathrm{c}}$ \\
\hline
\end{tabular}

\subsection{Influences of Plant Species on Water Quality}

After analysis of filtrated wastewater samples of those 9 main plots, the results found the averaged values as shown in Table 2. The BOD removal efficiencies of Typha angustifolia Linn., Cyperus corymbosus Rottb., and Canna indica Linn., were $88.47 \%, 82.16 \%$, and $86.62 \%$, respectively. The concentration of BOD were removed by Typha greater than Cyperus and Canna. For making clear understanding the function of the vertical flow on aquatic plant filtration plots under the concept of constructed wetland, the water quality indicators was taken an account with BOD as the representative. In principles, the organic matter has to be digested by aerobic and anaerobic processes at the top-layer wastewater and the middle-layer soil growing media during vertical flow into the bottom of constructed wetlands. The results were related to Leto et al. (2013) who reported that Typha had a good level of BOD removal efficiency (72.4\%) and higher BOD removal efficiency than Cyperus (64.8\%), and Abou-Elela and Hellal (2012) reported that average BOD removal efficiency were $92 \%$ for Canna, Phragmites, and Cyperus with vertical flow constructed wetland(VFCW). The quality of treated effluent proved that the use of VFCW as a treatment step was an efficiency technology for small community wastewater treatment. The high removal efficiency of BOD was rapidly removed by deposition and filtration, while organic compounds were degraded both aerobic and anaerobically by the heterotrophic microorganism depending on oxygen concentration in the system.

Total suspended solid (TSS) removal efficiency of Cyperus (58.77\%) was higher than Typha (48.47\%), and Canna, (47.91\%), respectively, while the efficiency of total nitrogen and total phosphorus removal were not significantly different among species. Although many reports demonstrated that Canna was high nutrient removal efficiency due to Canna were high growth rate (Konnerup et al., 2009) and Typha were plants that were able to establish successfully for high concentration of nutrient in wastewater treatment system (Calheiros et al., 2007), but differences in the removal of nitrate and BOD among plant species were due to differences in chlorophyll fluorescence, a photosynthetic characteristics, leading to different root lengths and total root biomass. Oxygen release to rhizosphere by wetland plant was directly governed by total root biomass and significantly influences the removal of ammonia and total dissolved phosphorus and chemical oxygen demand resulted from the filtration by root system. Nutrient uptake capacity was likely related to habitat preference and influenced by the structure of roots and rhizome. However, non-species-specific significant positive correlation was found between root oxygen release, root porosity, and radial oxygen loss rates were also positively correlated with plant tolerance to domestic wastewater and removal of total nitrogen and total phosphorus, hence nutrient removal might be not significantly different among species (Zhang et al., 2009; Li et al., 2013; Mei et al., 2014). Furthermore, the chosen species of aquatic plants were more efficient for the removal of pollutants in the long term. The different of pollutant removal efficiency among aquatic 
plant species were more not extremely great, especially in short period. The effect of aging on main parameters involved in pollutant removal in small constructed wetland such as temperature, $\mathrm{pH}$, conductivity, dissolved oxygen concentration and redox potential (Hijosa-Valsero et al., 2012; Konnerup et al., 2009).

Table 2. Water quality indicators of vertical flow constructed wetland (VFCW) as collected at the inlet and outlet of constructed wetlands for community wastewater treatment in Phetchaburi province, Thailand

\begin{tabular}{lccccc}
\hline & & \multicolumn{3}{c}{ Effluent } \\
\cline { 4 - 6 } Parameter & Unit & Influent & Typha angustifolia Linn. & $\begin{array}{c}\text { Cyperus corymbosus } \\
\text { Rottb. }\end{array}$ & Canna indica Linn. \\
\hline $\mathrm{pH}$ & - & 6.4 & $6.5^{\mathrm{a}}$ & $6.5^{\mathrm{a}}$ & $7.0^{\mathrm{a}}$ \\
$\mathrm{TSS}$ & $\mathrm{mg} / \mathrm{l}$ & 35.9 & $18.5^{\mathrm{b}}$ & $14.8^{\mathrm{a}}$ & $18.7^{\mathrm{b}}$ \\
$\mathrm{BOD}$ & $\mathrm{mg} / \mathrm{l}$ & 26.9 & $3.1^{\mathrm{a}}$ & $4.8^{\mathrm{b}}$ & $3.6^{\mathrm{a}}$ \\
$\mathrm{TN}$ & $\mathrm{mg} / \mathrm{b}$ & 7.1 & $4.2^{\mathrm{a}}$ & $4.6^{\mathrm{a}}$ & $4.5^{\mathrm{a}}$ \\
$\mathrm{TP}$ & $\mathrm{mg} / \mathrm{l}$ & 4.2 & $2.6^{\mathrm{a}}$ & $2.1^{\mathrm{a}}$ & $2.8^{\mathrm{a}}$ \\
\hline
\end{tabular}

\subsection{Influences of Rhizobacterium on Wastewater Treatment Efficiency}

Typha angustifolia Linn., Cyperus corymbosus Rottb., and Canna indica Linn. were determined for the number of rhizobacterium in small constructed wetland system. Typha was found $8.27 \times 10^{6} \mathrm{CFU} / \mathrm{g}$ and $1.69 \times 10^{7} \mathrm{CFU} / \mathrm{g}$ in the first day and 71days of the experimental periods, respectively. Cyperus was found $6.49 \times 10^{6} \mathrm{CFU} / \mathrm{g}$ and $2.82 \times 10^{8}$ $\mathrm{CFU} / \mathrm{g}$ in 57 days and very less in 71 days of the experimental period, respectively. The number of rhizobacterium in Canna was found about $3.97 \times 10^{6} \mathrm{CFU} / \mathrm{g}$ in the first day, $3.18 \times 10^{7} \mathrm{CFU} / \mathrm{g}$ in 43 days, and $1.37 \times 10^{7} \mathrm{CFU} / \mathrm{g}$ in 71 days of the experimental period, respectively (Table 3). The number of rhizobacterium were increased by period of plant growth, the highest number of rhizobacterium at the flowering stage, and decreased in the old stage because influences of exudates substrate from plant roots which were carbon and energy sources for bacteria growth (Sylvia et al., 1998; Gupta et al., 2000; Michael et al., 2000; Walker et al., 2003; Ibekwe \& Grieve, 2004). The number of rhizobacterium in each stage of plant growth was significantly different at the level of 0.05 .

Table 3. The number of rhizobacterium in Typha angustifolia Linn., Cyperus corymbosus Rottb. and Canna indica Linn. in Constructed Wetland System for Phetchaburi Municipal Wastewater Treatment

\begin{tabular}{cccc}
\hline \multirow{2}{*}{ Days } & \multicolumn{3}{c}{ The Number of Rhizobacterium (CFU/g) } \\
\cline { 2 - 4 } & Typha angustifolia Linn.(TA) & Cyperus corymbosus Rottb.(CC) & Canna indica Linn.(CA) \\
\hline 1 & $8.27 \times 10^{6 \mathrm{c}}$ & $6.49 \times 10^{6 \mathrm{~b}}$ & $3.97 \times 10^{6 \mathrm{a}}$ \\
15 & $2.24 \times 10^{6 \mathrm{a}}$ & $5.70 \times 10^{6 \mathrm{~b}}$ & $1.80 \times 10^{7 \mathrm{c}}$ \\
29 & $8.70 \times 10^{6 \mathrm{a}}$ & $2.29 \times 10^{7 \mathrm{~b}}$ & $2.50 \times 10^{7 \mathrm{~b}}$ \\
43 & $8.97 \times 10^{6 \mathrm{a}}$ & $2.57 \times 10^{8 \mathrm{c}}$ & $3.18 \times 10^{7 \mathrm{~b}}$ \\
57 & $1.42 \times 10^{7 \mathrm{a}}$ & $2.82 \times 10^{8 \mathrm{c}}$ & $2.10 \times 10^{7 \mathrm{~b}}$ \\
71 & $1.69 \times 10^{7 \mathrm{~b} *}$ & $1.79 \times 10^{7 \mathrm{~b}}$ & $1.37 \times 10^{7 \mathrm{a}}$ \\
\hline
\end{tabular}

Note: * flowering stage.

Isolation and identification of rhizobacterium were performed 73 isolate from root of three selected plants. Typha angustifolia Linn. was found 3 genus such as Bacillus sp., Enterobacter sp. and Flavobacterium sp. The 4 genus were found in Cyperus which were Bacillus sp., Pseudomonas sp., Micrococcus sp. and Aeromonas sp. and in Canna were found 5 genus as Bacillus sp., Xanthomonas sp., Corynebacterium sp., Azotobacter sp. and Pseudomonas sp. Bacillus sp were the most generally found in each species. Other bacteria species were found Arthrobacter sp., Pseudomonas sp., Azotobacter sp., Xanthomonas sp., Micrococcus sp., Corynebacterium sp. and Acinetobacter sp. The report of Calheiros et al. (2009) showed that Bacillus sp. and Pseudomonas sp. were found in Typha latifolia in constructed wetland. The number of rhizobacterium affected to the efficiency of wastewater treatment, due to organic substrates from community wastewater, were also digested by most of these bacteria which were heterotrophic bacteria. Metabolic profiles of microbial community in wetland only depended on the presence of plants but did not depended on the plant functional group level. Diversity of microbial community all were not significantly affected by the plant functional group richness level, appearing that total shift in microbial community in the constructed wetland only depended on the presence of plant species. Increasing in plant species richness microbial biomass carbon and nitrogen and utilization of amino acids but limited the utilization of amine and amides (Zhang et al., 2010; Zhang et 
al., 2011). Furthermore, bacteria community change related to the type of substrate different hydraulic loading and constructed wetland operation. (Gupta et al., 2000; Misko \& James, 2002; Dilfuza \& Gisela, 2003; Janis et al., 2003)

\section{Conclusion}

The three aquatic plants were selected for 9-small experimental plots which were vertical-flow constructed wetland (VFCW). There were Typha angustifolia Linn., Cyperus corymbosus Rottb., and Canna indica Linn. All of plants were particular formed in tropical countries like as Thailand. The findings showed that the priority for plant selection depended on high efficiency of BOD removal, growth rate, biomass, and the number of rhizobacterium, which played important role to remove contaminants from wastewater. Typha was the first priority selection for small wetland domestic wastewater treatment system due to higher growth rate, biomass, and efficiency of BOD removal than other species. Although, the number of rhizobacterium of Typha was less than Cyperus and Canna, but the previous studies showed that microbial community were not significantly affected by the plant functional group richness level, drove the shift in microorganism for utility miscellaneous compound in constructed wetland system. Furthermore, Typha had been grown well, common occurred in everywhere, and cutting leaves of them could be made for handicrafts. Canna might be considered for small wetland domestic wastewater treatment system because of its flowers may be preferred in aesthetic condition. Hence, adaptability of a species to climatic conditions in order to ensure maximum results from the aquatic plants in wastewater treatment should be considered.

\section{Acknowledgments}

We are also in debt to The Chaipattana Foundation for conducting and supporting this study. We would like to give thanks to the staff of Eco-Science Community Group (ESCG), Department Environmental Science, Faculty of Environment, Kasetsart University for facilitating the research fund, personnel, and laboratories. With appreciation, we are thankful to our colleagues of The King's Royally Initiative Laem Phak Bia Research and Development Project for their hard working from year 1990.

\section{References}

Abou-Elela, S. I., \& Hellal, M. S. (2012). Municipal wastewater treatment using vertical flow constructed wetlands planted with Canna, Phragmites, and Cyperus. Ecological Engineering, 47, 209-213. http://dx.doi.org/10.1016/j.ecoleng.2012.06.044

APHA. (1992). Standard Methods for the Examination of water and Wastewater (18th ed.) American Public Health Association and Water Environmental Foundation EPS group, Inc., Maryland.

Calheiros, C. S. C., Duque, A. F., Moura, A., Henriques, I. S., Correia, A., Rangel, A. O. S. S., \& Castro, P. M. L. (2009). Substrate effect on bacterial communities from constructed wetlands planted with Typha latifolia treating industrial wastewater. Ecological Engineering, 35, 744-753. http://dx.doi.org/10.1016/j.ecoleng. 2008.11.010.

Calheiros, C. S. C., Rangel, A. O. S. S., \& Castro, P. M. L. (2007). Constructed wetland systems vegetated with different plants applied to the treatment of tannery wastewater. Water Research, 41, 1790-1798. http://dx.doi.org/10.1016/j.waters.2007.01.012

Chunkao, K., Nimpee, C., \& Duangmal, K. (2012). The King's initiative using water hyacinth to remove heavy metals and plant nutrients from wastewater through Bueng Makkasan in Bangkok Thailand. Ecological Engineering, 39, 40-52. http://dx.doi.org/10.1016/j.ecoleng.2011.09.006

Cui, L. H., Ouyang, Y., Chen, Y., Zhu, X. Z., \& Zhu, W. L. (2009). Removal of total nitrogen by Cyperus alternifolius from wastewater in simulated vertical-flow constructed wetlands. Ecological Engineering, 35, 1271-1274. http://dx.doi.org/10.1016/j.ecoleng.2009.05.017

De Souza, M., Zhu, Y., Zayed, A., Quiana, J., \& Terry, N. (1999). Phytoaccumulation of trace elements by wetland plants: II Water Hyacinth. Journal of Environmental Quality, 28, 339-344. http://dx.doi.org/10.2134/jeq999.00472425002800010042x

Delost, M. D. (1997). Introduction to Diagnostic Microbiology: A Text and Wordbook. Morby, Year Book, Missouri.

Dilfuza, E., \& Gisela, H. (2003). Influence of growth-promoting bacteria on growth of wheat in different soils and temperatures. Soil Biology \& Biochemistry, 35, 973-978. http://dx.doi.org/10.1016/s0038-0717(03) 00158-5

Grofse, W., \& Bauch, C. (1991). Gas transfer in floating-leaved plants. Plant Physiology, 97, 185-192. http://dx.doi.org/10.1007/BF00035391

Gupta A. K., \& Sinha, S. (2007). Phytoextraction capacity of the plants growing on tannery sludge dumping sites. Bioresource Technology, 98, 1788-1794. http://dx.doi.org/10.1016/j.biotech.2006.06.028 
Gupta, A, Gopal, M. \& Tilak, K. V. (2000). Mechanism of plant growth promotion by rhizobacteria. Indian Journal of Experimental Biology, 9, 856 - 862. http://dx.doi.org/10.1016/jksus.2013.05.001

Hammer, D. A. (1989). Constructed wetlands for wastewater treatment-municipal, industrial, and agricultural: Chelsea. Michigan. Lewis Publishers, Inc., USA.

Hasan, S. H., Talat, M., \& Rai, S. (2007). Sorption of cadmium and zinc from aqueous solutions by water hyacinth (Eichornia crassipes). Bioresource Technology, 98, 918-928. http://dx.doi.org/10.1016/j.biotech. 2006.02.042

Hijosa-Valsero, Sidrach-Cardona, M., R., \& Becares, E. (2012). Comparison of international removal variation of various constructed wetland types. Science of the Total Environment, 430, 174-183. http://dx.doi.org/10.1016/j.scitotenv.2012.04.072

Ibekwe, A. M., \& Grieve, C. M. (2004). Changes in developing plant microbial community structure as affected by contaminated water. Ferm Microbiology Ecology, 48, 239-248. http://dx.doi.org/10.1016/j.ecoleng. 2009.05.017

Janis, C. K., Diane, F. Y., John, M. M., Robert, L. Q., Fred, J. G., Cynthia, A. C., \& Richard, D. (2003). Effect of light reduction on growth of the submerged macrophyte Vallisneria americana and the community of root-associated heterotrophic bacteria. Journal of Experimental Marine Biology and Ecology, 291, 199-218. http://dx.doi.org/10.1016/s0022-0981(3)00120-5

Kantawanichkul, S., Kladprasert, S., \& Brix, H. (2009). Treatment of high-strength wastewater in tropical vertical flow constructed wetlands planted with Typha angustifolia and Cyperus involucratus. Ecological Engineering, 35, 238-247. http://dx.doi.org/10/1016/j.ecoleng.2008. 06.002

Keddy, P. A. (2010). Wetland Ecology: Principles and Conservation (2nd ed.). Cambridge University Press, Cambridge, UK.

Khan, S., Ahmad, I., Shah, M. T., Reman, S., \& Khaliq, A. (2009). Use of constructed wetland for the removal of heavy metals from industrial wastewater. Journal of Environmental Management, 90, 3451-3457. http://dx.doi.org/10.1016/j.jenvman2009.05.026

Konnerup, D., Koottatep, T., \& Brix, H. (2009). Treatment of domestic wastewater in tropical, subsurface flow constructed wetlands planted with Canna and Heliconia. Ecological Engineering, 35, 248-257. http://dx.doi.org/10.1016/j.ecoleng.2008.04.018

Leto, C., Tuttolomondo, T., Bella, S. L., Leone, R., \& Licata, M. (2013). Effects of plant species in a horizontal subsurface flow constructed wetland-phytoremediation of treated urban wastewater with Cyperus alternifolius L. and Typha latifolia L. in the West of Sicily (Italy). http://dx.doi.org/10.1016/ j.ecoleng.2013.09.014

Li, L., Yang, Y., Tam, N. F. Y., Yang, L., Mei, X. Q., \& Yang, F. J. (2013). Growth characteristics of six wetland plants and their influences on domestic wastewater treatment efficiency. Ecological Engineering, 60, 382-392. http://dx.doi.org/10.1016/j.ecoleng.2013.09.014

Maier, R. M., Lan, L. P., \& Charles, P. G. (2000). Environmental Microbiology. Academic Press Publ, San Diego.

Maine, M. A., Syne, N., Hadad, H., Sanchez, G., \& Bonito, C. (2006). Nutrient and metal removal in a constructed wetland for wastewater treatment from a metallurgic industry. Ecological Engineering, 26, 341-347. http://dx.doi.org/10.1016/j.ecoleng.2013.09.044

Marin, J., \& Ayele, J. (2003). Removal of some heavy metal cations from aqueous solutions by spruce sawdust. Environmental Technology, 24, 491-502. http://dx.doi.org/10.1080/09593332308618334

Mei, X. Q., Yang, Y., N. Tam, F. Y., \& Wang, Y. W. (2014). Roles of root porosity, radial oxygen loss, Fe plaque formation on nutrient removal and tolerance of wetland plants to domestic wastewater. Water Research, 50, 147-159. http://dx.doi.org/10.1016/j.waters.2013.12.004

Metcalf \& Eddy. (1979). Wastewater Engineering: treatment, disposal, reuse (2nd ed.). McGraw-Hill, New York, USA.

Michael, B. W., Chenh, Alphei, B. S., G. J., \& Stefan, S. (2000). Microbial-faunal interactions in the rhizosphere and effects on plant growth. J. Soil Biol, 36, 135-147. http://dx.doi.org/10.1016/s1164-5563(00)0159-1

Misko, A. L., \& James, J. G. (2002). Taxonomic and functional diversity of pseudomonads isolated from the roots

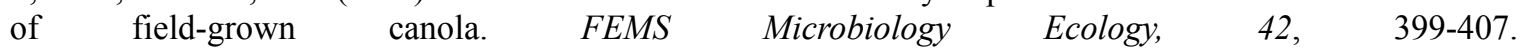
http://dx.doi.org/10.1111/j.1574-6941.2002.tb01029.x

Penha-Lopes, G., Flindt, M. R., Ommen, B., Kristensen, E., Garret, P., \& Paula, J. (2012). Organic carbon 
dynamics in a constructed mangrove wastewater wetland populated with benthic fauna: A Modeling approach. Ecological Modeling, 232, 97-108. http://dx.doi.org/10.1016/j.eco/model.2012.02.005

Pulford, I. D., \& Watson, C. (2003). Phytoremediation of heavy metal-contaminated land by trees-a review. Environmental International, 29, 529-540. http://dx.doi.org/10.1016/s0160-4120(02)00152-6

Rai, S., Hasan, S. H., Rupainwar, D. C., \& Sharma, Y. C. (1994). Removal of cadmium from wastewater by water hyacinth. International Journal of Environmental Studies, 46, 251-256. http://dx.doi.org/10.1080/ 00207239408710930

Reddy, K. R., Agami, M., \& Tucker, J. C. (1990). Influence of phosphorus growth and nutrient storage by water hyacinth plants. Aquatic Botany, 37, 355-365. http://dx.doi.org/10.1016/0304-3770(90)90021-c

Sylvia, D. M., Jeffry, J. F., \& David, A. Z. (1998). Principles and Applications of Soil Microbiology (8th ed.). Prentice Hall Publishing. Upper Saddle River, Inc., New Jersey.

Tateuyama, K., Egawa, H., \& Yamamoto, H. (1967). Don't waste water weeds. Weed Resource Japan, 22, $151-156$.

Thaipichitburapa, P., Meksumpun, C., \& Meksumpun, S. (2010). Province-based self remediation efficiency of the Tha Chin river basin, Thailand. Water Science and Technology, 62, 594-602. http://dx.doi.org/10.2166/ wst.2010.293

Wahla, I. H., \& Kirk, M. B. (2008). Heavy metal displacement in salt-water-irrigation soil during phytoremediation. Environmental Pollution, 155, 271-283. http://dx.doi.org/10.1016/j.envpol.2007.11.020

Walker, T. S., Pal, B. H., Grotewold, E., \& Vivanco, J. M. (2003). Root Exudation and Rhizosphere Biology. Plant Physiology, 132, 44-51. http://dx.doi.org/10.1104/pp.102.019661

Wenyin, C., Zhanghe, C., Qifan, H., Xiaoyan, W., Cairong, W., Dafeng, C., \& Zenglong, L. (2007). Root growth of wetland plants with different root types. Acta Ecologica Sinica, 27(2), 450-458. http://dx.doi.org/10.1016/ s1872-2032(07)60017-1

Wild, U., Kamp, T., Lenz, A., Heinz, S., \& Pfadenhauer, J. (2001). Cultivation of Typha spp. in constructed wetland for peatland restoration. Ecological Engineering, 17, 49-54. http://dx.doi.org/10.1016/s0925-8574(00)00133-6

Xia, H., \& Ma, X. (2006). Phytoremediation of ethion by water hyacinth from water. Bioresource Technology, 97, 1050-1054. http://dx.doi.org/10.1016/j.biotech.2005.04.039

Yang, Q., Tam, N. F. Y., Wong, Y. S., Laun, T. G., Su, W. S., Lan, C. Y., Shin, ... Cheung, S. G. (2008). Potential use of mangrove as constructed wetland for municipal sewage treatment in Futian, Shenzhen, China. Marine Pollution Bulletin, 57, 735-743. http://dx.doi.org/10.1016/j.ecoleng.2009.05.017

Ye, Y., Nora, F., Tam, Y., \& Wong Y. S. (2001). Livestock wastewater treatment by a mangrove pot-cultivation system and the effect of salinity on the nutrient removal efficiency. Marine Pollution Bulletin, 42, 513-531. http://dx.doi.org/10.1016/s0025-326x(00)00196.x

Zaier, H., Ghanaya, T., Rejeb, K. B., Lakhdar, A., Rejeb, S., \& Jemal, F. (2010). Effects of EDTA on phytoextraction of heavy metals $(\mathrm{Zn}, \mathrm{Mn}$, and $\mathrm{Pb})$ from sludge-amended soil with Brassica napus. Bioresources Technology, 101, 3978-3983. http://dx.doi.org/10.1016/j.biotech.2010.01.035

Zhang, C. B., Wang, J., Liu, W. L., Ge, H. L., Chang, S. X., Chang, J., \& Ge, Y. (2010). Effects of plant diversity on microbial biomass and community metabolic profiles in a full-scale constructed wetland. Ecological Engineering, 36, 62-68. http://dx.doi.org/10.1016/j.ecoleng.2007.09.010

Zhang, C. B., Ke, S. S., Wang, J., Ge, Y., Chang, S. X., Zhu S. X., ... Chang, J. (2011). Responses of microbial activity and community metabolic profiles to plant functional group diversity in a full-scale constructed wetland. Geoderma, 160, 503-508. http://dx.doi.org/10.1016/j.biotech.2010.01.035

Zhang, Z., Rengel, Z., \& Meney, K. (2009). Kinetics of ammonium, nitrate and phosphorus uptake by Canna indica and Schoenoplectus validus. Aquatic Botany, 91, 71-74. http://dx.doi.org/10.1016/j.geoderma.2010.10.020

\section{Copyrights}

Copyright for this article is retained by the author(s), with first publication rights granted to the journal.

This is an open-access article distributed under the terms and conditions of the Creative Commons Attribution license (http://creativecommons.org/licenses/by/3.0/). 